John Carroll University

Carroll Collected

History

2009

\title{
The Unspooling of Artkino: Soviet Film Distribution in America, 1940-1975
}

James H. Krukones

John Carroll University, jkrukones@jcu.edu

Follow this and additional works at: http:// collected.jcu.edu/hist-facpub

Part of the Film and Media Studies Commons

\section{Recommended Citation}

Krukones, James H., "The Unspooling of Artkino: Soviet Film Distribution in America, 1940-1975" (2009). History. 26.

http:// collected.jcu.edu/hist-facpub/26

This Article is brought to you for free and open access by Carroll Collected. It has been accepted for inclusion in History by an authorized administrator of Carroll Collected. For more information, please contact connell@jcu.edu. 


\section{The Unspooling of Artkino: Soviet Film Distribution in America, 1940-1975}

One evening in 1925 the guests at Gloria Swanson's Manhattan penthouse decided to watch a print of The Battleship Potemkin, the latest film of director Sergei Eisenstein. Lacking a screen, they hung one of their hostess' bedsheets on a wall.1 The Battleship Potemkin thus became the first Soviet movie shown in the USA. Thereafter, finding screens for Soviet films in America became more complicated.

This article examines the distribution of Soviet films in the USA by Artkino, the agency that long dominated the field. Overlooked by scholars in both film history and Russian studies, Artkino was in business for more than 30 years nearly half of the lifetime of the Soviet film industry and for 20 of those years it was virtually the sole US distributor of films from the USSR. Eventually its position was undermined by a combination of developments beginning in the mid 1950s, most of them related to the 'thaw' that occurred within the Soviet Union itself and in US Soviet relations. For that reason, the article devotes somewhat more attention to the later rather than the earlier period of Artkino's activity. Much of the material on which this study is based comes from the Artkino collections housed at the Museum of Modern Art in New York City and the Pacific Film Archive at Berkeley.2

Soviet film distribution around the world actually began in the Soviet Union itself. The export of movies was a monopoly: first, of Sovkino; then, between 1930 and the end of World War II, of Intorgkino; and finally, beginning in 1945, of Sovexportfilm, the All Union Association for the Export and Import of Films. This enormous entity remained the single official source of Soviet films outside the USSR until the country's collapse in 1991.3

[FIGURE 1 A wartime version of the Artkino logo that softens the ideological blow by substituting a star for the hammer and sickle. Source: The1945 Film Daily Year Book of Motion Pictures (NewYork, 1945),p.156.

In sending Soviet films abroad, Sovexportfilm and its predecessors only initiated a process that was completed by their counterparts all over the globe. These local companies had to be prepared to distribute films within the countries or regions in which they operated. In some cases these companies were subsidiaries of Sovexportfilm (or one of its earlier incarnations); in others they were film corporations that also released Soviet movies under their own banner.

In the USA, the first distributor of Soviet films (and forerunner of Artkino) was Amkino (American Cinema), founded in New York in November 1926. Beginning with The Battleship Potemkin hereafter beamed on screens rather than bedsheets Amkino enjoyed a monopoly of its own over Soviet film distribution; at the same time, it left production to the film studios back in the USSR and exhibition to theater owners in America. Amkino's distribution network was limited for the first several years of its existence, but by the mid 1930s it made available up to 20 recent Soviet features each year to the growing number of theaters in the USA and Canada that screened foreign language films. The 20 features were in addition to the newsreels, documentaries and even cartoons that also made up the Amkino catalog. After 13 years in the business, Amkino could claim credit for distributing over 160 Soviet films in the USA. The roster included classics from the silent era, such as Mother (1926/1934), Storm over Asia (1928/1930), October (1928), New Babylon (1929) and Earth (1930), as well as more recent sound features, for example, Chapaev (1934/1935), Maxim's Childhood (1935), both parts of Peter I (1937, 1938/1939), Baltic Deputy (1937) and Alexander Nevsky 
$(1938 / 1939) .4$

In February 1940, Amkino suddenly announced its impending dissolution due to a recent downturn in business. The New York Times suggested that several factors were responsible: a plummet in the quality of Soviet films in the late 1930s on account of growing Stalinist control over the industry; a reduction in the number of new film exports on the Soviet side; and, perhaps most devastating of all, the Soviet German Non Aggression Pact of August 1939 and subsequent Soviet military attacks on Poland and Finland, which significantly lessened the popularity of films from the USSR, even among the self selecting audience that was sympathetic to Soviet ideology and culture. 5 With the demise of Artkino, the fate of Soviet film exhibition in America appeared uncertain, but it did not remain so for long. The very next month, in March 1940, the Artkino Pictures Company came into existence. In its agreement with the Soviet government (specifically, Soyuzintorgkino), it was granted 'all rights to complete, sole and exclusive distribution' of Soviet films in North and South America. Several details made it clear that Artkino was picking up from where Amkino left off. For one thing, the names of the two companies bore a certain similarity. For another, Artkino took up residence at the same Seventh Avenue office that Amkino had called home. The new company stressed that it had no connection with the Soviet government, although subsequent advertising indicated that it was 'registered under the Foreign Agents Registration Act [FARA] as the American distributing agent for Soyuzintorgkino, Moscow, USSR, with the Department of Justice, Washington, D.C.' Moreover, one of its early logos appeared to be a variation on the 1937 sculpture by Vera Mukhina depicting a worker and peasant woman striding valiantly into the future, a star taking the place of the original hammer and sickle in their upraised hands. (The Mosfilm studio adopted Mukhina as its trademark a few years later.)Artkino immediatelybegannegotiations withlntorgkinotoacquiredistribution rights to several new Soviet titles and also made available much of Amkino's catalog of older features. Within a few months the exhibition of Soviet films in major urban markets not only New York but also Philadelphia, Boston, Cleveland, Detroit, Chicago, Los Angeles and San Francisco began to approach earlier levels.6

Also providing continuity were the individuals who came over to Artkino from Amkino. One gets the impression that putting Soviet films before the American public was a real labor of love for them. The president of Artkino from 1940 until his death in 1962 was Nicholas (Nicola) Napoli. Born in New York in 1905, Napoli was taken to Italy at a young age by his parents. He attended the Royal Technical Institute in Palermo, Italy, and then became the New York correspondent for several Italian newspapers. He subsequently worked as a printer, advertising man, freelance writer and translator before joining Amkino in 1929; in that organization he served as assistant to the president. Napoli's successor as head of Artkino was his former assistant and company vice president Rosa Madell, who, at Amkino, had worked as a film booker. Years later Rosa would remember seeing The Battleship Potemkin on New Year's Eve in 1926, accompanied by the man she married a few months thereafter. The film made them, in her own words, 'instant fans of the Soviet screen.' Rosa remained Artkino president until her own death in 1970, after which her husband Sam took over the company. It was Sam Madell who donated the Artkino archive to the Museum of Modern Art in 1975 and the Madells' son Tom who donated additional materials to the Pacific Film Archive in 2002.7

Artkino got off to a slow start; in its first year the new company released only two 
Soviet feature films. Its business fortunes soon received a shot in the arm from the entry of the USSR into World War II in June 1941. The Soviet film industry, like its counterparts8in the other belligerent countries, reoriented production to serve the war effort. This was clearly reflected in the film programming of Artkino. It distributed a variety of newsreels and documentaries that detailed the major campaigns along the Eastern Front and the grim determination with which the Soviet people met the aggressor; titles included Moscow Strikes Back (1942), Siege of Leningrad (1942), The Russian Story (1942), Ukraine in Flames (1943/1944) and People's Avengers (1943/1944). The full length dramatic features that Artkino added to its catalog during these years also tended to focus on the war. We Will Come Back (1942/1943), for example, dealt with Russian guerrilla fighters working behind enemy lines. No Greater Love (1943/1944), The Rainbow (1944) and Zoya (1944/1945) all stressed Nazi bestiality and the holy wrath this provoked in its Russian victims. Girl No. 217 (1945) took essentially the same story but changed the location to Germany; its protagonists were Soviet slave laborers groaning under the yoke of the callous and stupid Hun. Wait for Me (1943/1945) dramatized the widespread concern over the fidelity of home front Soviet wives to husbands they might never see again. Even a musical romance such as Six P.M. (1944/1946) used the war as a backdrop for its pair of lovers, who planned a rendezvous on a Moscow bridge as soon as hostilities ceased.

A few releases left the war far behind, although these were clearly in the minority. Among them were literary adaptations such as Masquerade (1941/1943) (based on Mikhail Lermontov's poetic drama) and Marriage (1944/1945) (based on the play by Anton Chekhov); light hearted musicals such as Taxi to Heaven (1943/1944) and Hello, Moscow! (1945/1946); and historical dramas, for instance, Adventures in Bokhara (1943/ 1944) (about the legendary people's hero Nasredin) and 1812 (1944) (a biography of General Mikhail Kutuzov, but even here the movie had strongly emphasized parallels to the ongoing conflict).

In the decade following World War II, Artkino remained the dominant, indeed the sole, distributor of Soviet films in the USA. The Soviet (and, at this time, almost invariably Russian language) movies that Americans saw were determined by a combination of what Sovexportfilm had to sell and what Artkino opted to buy. Early in 1946, Napoli, who had enthusiastically marketed Artkino's war themed fare, paid a three month visit to Moscow to survey the contemporary film scene. He returned with optimistic predictions that the Soviet Union soon would be producing between 80 and 100 feature films a year.9 That proved far off the mark; in fact, in the immediate postwar years, Soviet film making experienced its creative nadir. Bureaucratic control joined forces with the dictates of socialist realism to squelch artistic expression. Moreover, the official insistence on limiting production to cinematic 'masterworks' led to a drastic reduction in the number of feature films actually made. What did appear in movie theaters during this period of 'film hunger,' moreover, was mostly banal and formulaic. Nonetheless Artkino did its best to keep Soviet film represented on American screens. Perhaps the artistically most compelling film it brought to the USA at this time was the first part of Sergei Eisenstein's planned trilogy on Tsar Ivan the Terrible, which actually had been completed and released in the USSR in 1944. (Ironically, by the time the film began its playdates in the USA early in 1947, Part II had already opened in the Soviet Union, where its conflicted portrayal of the title character resulted in its withdrawal from circulation for the next 12 years.)

Ivan the Terrible (1944/1947), however, was the exception. As a rule, American 
viewers were restricted to more fare of the kind they already had encountered during the war years, if not before. For example, documentaries no longer concentrating on battles and the military preparedness of the Soviet people now dealt with bland subjects such as Secrets of Nature (1950) or Moscow's 800 ${ }^{\text {th }}$ Anniversary (1947/1949), while occasionally setting foot on more overtly political turf with, say, The New China (1950/1952). Musical films continued to include crowd pleasers created expressly for the screen (e.g. The Lucky Bride [1947/1948], Cossacks of the Kuban [1949/1950]) as well as high toned compilations of the classics (Concert of Stars [1952/1953], Stars of the Russian Ballet [1953/1954]). A few comedies and children's films made their appearance as well, even the first Soviet feature length animated cartoon, The Magic Horse (1947/1949). The films that set this period apart, however, belonged to different categories. One kind cast Stalin in the central role, reflecting the unparalleled heights that his personality cult by now had achieved. For example, in The Fall of Berlin (1949/1952) and The Battle for Stalingrad (the latter released in the USA as two films, The First Front (1949) and The Victors and the Vanquished (1950)), Stalin emerges as a calm and all knowing military genius, singlehandedly responsible for the defeat of Nazi Germany and its hysterical Führer. Following in the footsteps of the leader during these years were film biographies of distinguished Russians from the tsarist era, in a respectful nod to the pre Soviet past that had characterized Stalinist culture since the mid 1930s. Subjects included the composers Mikhail Glinka (the subject of two biopics during this period), Modest Musorgsky and Nikolai Rimsky Korsakov; the scientists Ivan Michurin and Ivan Pavlov; Admirals Pavel Nakhimov and Feodor Ushakov; and the Ukrainian (but conveniently anti tsarist) writer Taras Shevchenko. Stories of a more contemporary nature tended to focus on the achievements of industry (Miners of the Don [1950/1951]) or agriculture (Bountiful Summer [1950]), reaffirming official Soviet determination to rebuild their war torn economy as quickly as possible. Of the films unique to these years, there was one variety to which Artkino refrained from acquiring distribution rights. Dubbed 'publicistic films' by historian Peter Kenez, they dramatized the anti Soviet machinations of Cold War enemies, usually Britain and the USA, and likely had little appeal even for that specialized Western audience interested in the Soviet cinema.10

The immediate postwar years saw a dramatic rise in the popularity of foreign language films in the USA, especially from Western European countries such as France and Italy. The 'art houses' that exhibited these films began to grow in number, too.11 Soviet films did not participate in this phenomenon; Cold War tensions and the generally abysmal state of Soviet film making restricted them to a ghetto of their own. With the death of Stalin in 1953, however, a major change got underway. Soviet leader Nikita Khrushchev (1894 1971) initiated a campaign of de Stalinization that dismantled the worst aspects of the terror system that had come into being under his predecessor. One aspect of de Stalinization was a 'thaw' that, in lifting some of the most oppressive controls on Soviet state and society, proved especially encouraging to Soviet artists, including film makers. They took advantage of the new creative freedom to challenge the orthodoxy of socialist realism, whose heavy handed political messages had to be readily accessible to the masses. The emphasis now shifted from the Party to the personal, from the collective to the individual, from the monumental to the intimate. As a result, Soviet movies began to regain some of the piquancy and quality for which they had been acclaimed around the world in the 1920s.12

The onset of the thaw in Soviet film occurred within a year or so of Stalin's demise in 1953. Taking into account the inevitable gap between the opening of a film in the USSR and its foreign release, thaw films started reaching US moviegoers by the middle 
of the decade. Furthermore, the cinematic thaw, like that affecting Soviet society as a whole, evolved slowly and sporadically rather than emerging all at once. For the sake of this discussion, the period will be considered in two parts, divided by the year 1960. Until then, Artkino remained the exclusive distributor of Soviet films in the USA. (The only exception to this rule occurred in the case of The Ballet of Romeo and Juliet (1955/1956), which impresario Sol Hurok acquired, apparently in conjunction with his sponsorship of an American tour by the Bolshoi Ballet and its star performer GalinaUlanova.)13

Between 1955 and 1960, Artkino distributed 72 Soviet films in the USA, 21 of which were documentaries. Tellingly absent are the 'personality cult' films, with their hosannahs to Generalissimo Stalin, and the plodding biopics that extolled notable Russians in various walks of life. Just the same, many of the films of the late 1950s fall into familiar categories, indicating a basic continuity within the film industry and, for that matter, in the operation of Artkino as well. Ballet and opera films rubbed shoulders with musical comedies and variety show compilations of song and dance. Literary adaptations remained common, too, as did historical dramas and straightforward documentaries, both feature length and short subject.

A few films in particular, however, indicated that the Soviet film industry had begun to turn a corner. By the standards of Western cinema, these films would have appeared unremarkable on the surface, but that was precisely what made them noteworthy. On the whole, they emphasized human, individual values and downplayed, if not altogether removed, the role of Party and state. Moreover, the way they treated these situations made their characters and situations more believable to audiences. In other words, their realism was not of the socialist variety. Of this relatively small group of movies, one of the first to be released in the USA was A Big Family (1954/1955).14 While this melodrama about several generations of shipyard workers may have looked like a typical Soviet paean to the nobility of labor, it also allowed the many members of the Zhurbin clan to work out their own problems without interposing the Communist Party and its infallible guidance. The family's problems, moreover, included elements that would have shocked Soviet moviegoers of the day, such as an out of wedlock pregnancy and marital break up.

A few months after the release of A Big Family, Conflict (1955) not only made one of its central characters an unfeeling careerist but also portrayed his wife as unswervingly loyal to her husband, even in the face of Party criticism. In The Case of Sergey Rumyantsev (1955/1956), a police investigator doggedly pursues the real criminals after concluding that the title character had been framed. 'We must treat every Soviet citizen with the utmost consideration,' he tells a co worker, as though reassuring audiences that the era of Stalinist illegality had come to an end. In a remake of the Civil War tale The Forty First (1956/1957), the Red heroine seemingly allows revolutionary duty to triumph over personal feeling when, in the end, she shoots the White prisoner with whom she has fallen in love; it is, however, their passionate romance and her ultimate grief, rather than any sense of ideological obligation, that dominate the film. The Party itself came in for some good natured ribbing in Carnival in Moscow (1956/1957), a musical comedy that centers on a New Year's celebration at a Moscow house of culture. The stuffy and overbearing (read: Stalinist) director wants a staid and officious ceremony, but his plans eventually give way to a jazz flavored jamboree staged by his younger colleagues. Even World War II, the epicenter of the Soviet experience, started coming into new focus, but no longer as the ultimate triumph and justification of the 
Stalinist regime. Instead, The House I Live In (1957/ 1959) shunned political proclamations and battlefield heroics for a quiet and moving look at the impact of the war on the residents of a Moscow apartment building.15 Finally, while hardly a 'thaw' film, Ivan the Terrible Part II had its US premiere, well over a year after its unveiling at the Brussels World's Fair in 1958. In 1946, its controversial portrayal of the tsar then officially extolled as a forerunner of Stalin had gotten director Eisenstein into political hot water and ruined plans for a third installment. Now, however, with the dictator in his tomb and de Stalinization well underway,Eisensteinwaspermitted hissay.

In short, the films released in the USA through Artkino during the second half of the 1950s reflected changing trends in Soviet cinema. The distributor even chose to emphasize this in some of its advertising.16 But advertising was only one of its many activities. From the founding of the company as the successor to Amkino in 1940 until the winding down of its operations in the early 1970s, Artkino did everything possible to place Soviet made films in US theaters. Certainly its most essential task was negotiating with Sovexportfilm exactly which films it wished to acquire for US distribution. This involved occasional trips to the USSR by Napoli and later the Madells, who would eventually take advantage of the Moscow Film Festivals to preview the latest Soviet films.17 In the main, however, the company's work took place back in the States. With the help of Russian and English texts of the dialogue provided by Sovexportfilm, Artkino added English subtitles on most film prints that it received, as well as opening credits in English that began with a credit for itself ('Artkino Presents'). 18 Artkino also made cutsusually small ones in the films, but any edits required prior Soviet permission. In the 1940s, the company had its own film editor, but by the 1960s it sent the films to a lab instead. As an example, in a conversation between two main characters in Nine Days of One Year (1962/1964), a couple of brief references to Communism were left on the cutting room floor, not for ideological reasons but rather because the allusions would have been meaningless to most American viewers.19

Another important aspect of Artkino's work was packaging film programs. Often a dramatic feature was coupled with a documentary or some other kind of short subject, in the manner of Western film programs of the era. Carnival in Moscow, for instance, was simply the upper half of a program that also included In the Antarctic (1956), a 20 minute record of a Soviet scientific expedition's visit to the South Pole. In the case of The Dragonfly (1954/1955), a musical comedy, the lower half of the bill consisted of a 20 minute dramatization of Anton Chekhov's short story Ladies. On occasion the entire program consisted of documentaries, as when Road to the Stars (1958), which dealt with space travel, was paired with The World Dances (1958), based on performances at 1957's World Youth Festival in Moscow. Less frequently, a documentary program would consist of a single film that incorporated several individual shorts on different subjects. The two hour Inside the U.S.S.R. (1961), for example, included Moscow Story, On Ice and Water and Prokofiev His Life and Music. In one instance, Rosa Madell herself edited the 100 minute Cavalcade of Russian Ballet and Dance from footage preserved in Soviet state cinema archives. 20

Artkino also walked Soviet films through the process of applying for exhibition licenses. Such permission had to be sought from different agencies depending on the jurisdiction. In New York, Pennsylvania and Ohio, for example, this matter fell under the state education department. Richmond, Virginia, and Milwaukee, Wisconsin, had separate film boards that issued approval, whereas Chicago required a signature from the police superintendent. Certainly Soviet films of this era, unlike films from other 
foreign countries, contained nothing with respect to language, sex, or violence that would offend censorship boards.21 Similarly, whatever the propaganda content of the Soviet films distributed by Artkino, there is little in the archival materials to suggest that it raised official hackles. Nevertheless problems could arise in places where they might not have been anticipated. Festival in Moscow (1957/1958), for instance, documented the official activities of the 60,000 participants in the 1957 World Youth Festival in Moscow, including 'almost every conceivable type of singing and dancing . . . endless parades, a water regatta and a magnificent fireworks display near the end.' With English narration to boot, the film would have seemed destined for a quick pass. The Education Department of the State of New York, however, insisted that Artkino submit an English translation of all of the songs heard in the film. The distributor responded with an affidavit attesting to the unavailability of the song texts (the film had been shot by roving newsreel cameramen) and the unintelligibility of the lyrics due to the quality of the sound track.22

Artkino shipped prints to theaters, film societies and colleges across the country. Some were customers of long standing. The best examples come from New York City, the site of Artkino's headquarters as well as the center of US foreign film exhibition. For more than 14 years (nearly half the time that Artkino was in business), the Stanley Theater on Times Square was Manhattan's showcase for Soviet films. It opened in September 1941 with General Suvorov (1941) and rang down the curtain at the end of 1955 with Conflict. The draft of a press release prepared for the theater's first anniversary noted that it had 'steadily mounted in popularity, until today, the Stanley's mailing lists constitute a representative cross section of New York's population.' Stanley audiences, it appears, were favorably disposed toward Soviet films, no matter what the content. The New York Times reviewer of Village Teacher (1947/1948), a Stalin era ode to Soviet achievements, called it 'fine fare for the regular Stanley clientele who, judging by their reaction, love their propaganda to be laid on with a mighty heavy hand.'23

When the Stanley closed, Artkino found another outlet for its programs, the Cameo. Its location on Eighth Avenue suggested a degree of removal from the mainstream; in fact, in an earlier incarnation as the Squire, the theater had specialized in what critic Bosley Crowther coyly referred to as 'girlie' films. (At a time when 'art house' cinemas were beginning to cater to their elite clienteles with special seating and gourmet refreshments, the relatively low rent status of the Stanley and Cameo offers additional evidence that Soviet films did not at first share in the postwar popularity of foreign films in the USA.) Ironically, this was not the first time the Cameo featured Soviet films. For several years during the 1930s it had shown movies from the USSR imported by Amkino. That relationship came to an end with the demise of Amkino in 1940. The Cameo kicked off its second Soviet period with the film version of Musorgsky's opera Boris Godunov (1955/1956) and ended it nearly a decade later with the irreverent comedy Welcome, Kostya! (1964/1965). While Artkino subsequently managed to book some of its films into more prestigious outlets (on several occasions in 1966, for example, the Regency, located a couple of blocks north of Lincoln Center), it never again enjoyed a long term relationship with a Manhattan theater.24 Nevertheless Artkino rented films to a wide variety of New York City cinemas and other organizations, including the major television networks and the National Council of American Soviet Friendship.

The second largest concentration of Artkino customers came from California, mostly the San Francisco and Los Angeles areas. Including New York and California, Artkino had business ties in 29 states as well as the District of Columbia by the 1960s.25 
In the late 1950s, Nicholas Napoli told Variety that a 'good' Soviet film could count on 100 theater bookings in the USA but that the average Russian import was likely to have between 20 and 40. He also pointed out that no US theater devoted itself exclusively to showing Soviet films.26 Artkino's advertising materials, furthermore, indicate that New York's Stanley and Cameo aside foreign film outlets in other parts of the country limited their exhibition of Soviet movies to several days a week (often Thursday through Sunday) rather than playing them all week long.

Getting films into theaters was only half the battle; getting audiences into theaters was the other half. While attracting customers was the business of theater owners, Artkino lent a hand wherever possible. Moreover, it was able to do more in the New York area than elsewhere. It sent press releases about upcoming movies to a wide variety of publications, including those whose readers could be presumed to have a special interest in film fare from the USSR, such as the Daily Worker, the e'migre 'Russian newspaper Novoe Russkoe Slovo (New Russian Word), and the Ukrainian News; these periodicals often returned the favor by reviewing the films on their pages. Radio advertisements were another means of attracting a mass audience. Artkino also invited critics to advance screenings. Even for theaters outside of New York, Artkino could provide a variety of advertising materials. Some of them brochures with pictures and English language text, for example came directly from Sovexportfilm. Others were prepared by the Artkino staff and incorporated blurbs from the US press. The company also offered posters, still photographs, press books and even trailers, some of which it cobbled together by itself, especially in the early days of the company. 27

An especially charming device was the mat, or printing mold, which was designed for newspaper advertisements. Usually no more than a couple of inches high and three or four inches wide, the mats featured sketches of the principal players in characteristic poses, a prominently displayed title, brief excerpts from reviews and a few credits, including (where appropriate) the mention of 'magnificent Magicolor.' The mats lacked the slickness of typical advertisements for American made films with their greater realism and size. Nonetheless, they linked the transcontinental efforts of Artkino to popularize the Soviet cinema abroad: an ad for Taras Shevchenko (1951/ 1952), for example, looked the same whether it announced the film's run at the Stanley in the New York Herald Tribune or at the Maynard in the Los Angeles Times.28 At the same time, the costs of purchasing space in a major publication such as the New York Times often made it necessary to keep advertisements tiny and limit them to bare bones information about the run of a film, minus any graphics whatsoever.

How long Artkino's dominance of the Soviet film distribution market in the USA might have continued is difficult to say. Even before 1960 new forces had come into play that eventually would undermine the control any one organization could hope to exert over the business. The initial icebreaker was the 'thaw' itself, especially as it began to affect relations between the Soviet Union and the USA. Khrushchev's doctrine of 'peaceful coexistence' laid the groundwork for constructive Soviet engagement with capitalist countries, which they readily pursued. An important facet of this engagement was the cultural exchange. This phenomenon even surfaced in the film programming of Artkino. For example, documentaries covered a US troupe performing George Gershwin's folk opera Porgy and Bess in the USSR and a visit to the Soviet Union by a delegation of American farmers.29 It was logical, perhaps even inevitable that a film swap should become part of the exchange agreements. Not only did both countries have large moviemaking industries and considerable product to trade; they also had a history 
of discussing the matter. While talks during the early postwar years had led to nothing, friendlier relations during the 'thaw' promised concrete results.30

The overall US USSR exchange agreement was signed in Washington, D.C., on January 27,1958 , and dealt in general terms with the fields of culture, technology and education.31 Over the course of the next several months, representatives of both sides worked out the details of the film exchange. Coincidentally, the chief American negotiator was Eric Johnston, president of the Motion Picture Export Association (MPEA), who had unsuccessfully tried to arrange a film exchange 10 years before. Now, with governmental support, he had more success. Johnston's Soviet counterpart was Alexander Davydov, president of Sovexportfilm, the organization with which Artkino had been dealing since the end of the war. Initially the Soviets demanded strict reciprocity so that, for every American film they agreed to show in the USSR, the Americans would play a Soviet movie in the USA. Johnston, however, feared that the acceptance of the reciprocity principle would set a precedent, causing other foreign film studios to insist on its application in their own dealings with American companies. Another issue revolved around the role of major US studios in the film exchange. To insure the most sophisticated marketing and widest possible distribution of the Soviet films in the USA (and thus placate the Soviets), Johnston persuaded the largest Hollywood film companies to become parties to the exchange; the smaller, independent firms that usually handled foreign films in the USA, he believed, would not be up to the task. In other words, Artkino need not apply. At the same time the US State Department eventually prohibited individual American studios from working out arrangements of their own with Sovexportfilm until the exchange agreement had been finalized. Under these circumstances, the participating American studios agreed to license their available motion pictures to the MPEA and allow it to bargain with the Soviets on behalf of all of them.32

The exchange agreement dealing specifically with films was concluded on October 9, 1958. It included provisions for the exchange of documentary films (15 from each side); the organizing of an American film week in the USSR and a Soviet film week in the USA; the exchange of film delegations (each consisting of up to 10 prominent film personalities) for month long visits designed to acquaint them with production techniques in the host country; and the discussion of the joint production of dramatic features, popular science films, and documentaries. The most prominent clause called for the US purchase of seven Soviet feature films and the Soviet purchase of 10 US features. Johnston had, in the end, accepted the reciprocity principle, but only up to a point. Each film would cost $\$ 60,000$ ( $\$ 67,000$ in the case of a widescreen feature). The films would be dubbed or subtitled by the country providing them, and any changes in content prior to their distribution in the receiving country required mutual agreement.33

Several more months passed before the lists of exchange films on both sides were complete. In the end, the Russians agreed to distribute the following American movies in the USSR: Beneath the Twelve Mile Reef (1953, 20th Century Fox; eventually replaced by All About Eve [1950, 20th Century Fox]), The Great Caruso (1951, MGM), Lili (1953, MGM), Man of a Thousand Faces (1957, Universal), Marty (1955, United Artists), The Old Man and the Sea (1958, Warner Bros.), Oklahoma! (1955, 20th Century Fox), Rhapsody (1954, MGM), Roman Holiday (1953, Paramount) and The Seventh Voyage of Sinbad (1958, Columbia). All of them were well crafted studio works, some superior to others, representing a variety of genres biopic, musical, romantic comedy, adventure and drama. In the case of the seven Soviet films chosen for US distribution, the selection typified what the Soviet film industry had been producing for the last several years and, 
for that matter, what Artkino had for some time been bringing US audiences. Five of the films had literary or classical pedigrees: The Idiot (1958), Othello (1955), Don Quixote (1957), And Quiet Flows the Don (1957) and Swan Lake (1957). Circus Stars (1957), a non narrative film, belonged to the variety genre.

Only The Cranes Are Flying (1957) critically the most acclaimed movie of the lotcould be considered a typical 'thaw' film in terms of content and tone. In fact, Cranes quickly attained a reputation as the defining film of the Soviet cinematic 'thaw.' Like The House I Live In, Cranes focused on human emotions played out against the backdrop of World War II. This moving drama of a young woman who must learn to cope with the battlefield death of her lover fit right into Khrushchev's de Stalinization campaign then gaining momentum. Neither Stalin's name nor image is anywhere to be found in the recreation of an era over which he had towered not long before; the doomed boyfriend even keeps a miniature bust of Lenin on his desk, as though to suggest the official rededication of the country to the ideals of the revolution before their perversion by the personality cult. Cranes captured the top prize at the Cannes Film Festival of 1958, an indication of the renewed international stature of post Stalin Soviet cinema.34

Enthusiastically supported by both sides, the film exchange was launched with much fanfare. In November 1959, twin premieres attended by luminaries from the worlds of politics and entertainment took place in Moscow and Washington, D.C. Americans got their first look at The Cranes Are Flying, while the Russians viewed Marty (1955), an Oscar winning intimate portrayal of human relationships that served as an appropriate counterpart to the Soviet film. Reactions of opening night audiences and critics in both capitals were favorable and often enthusiastic. 35 Over the course of the next year or so, all of the exchange films would begin runs throughout the USSR and the USA. The major Hollywood studios had drawn lots to determine which of the Soviet films they would be responsible for marketing and distributing. Cranes had gone to Warner Bros., while Columbia had landed Swan Lake (the other Soviet film considered particularly desirable because of potential box office appeal). And Quiet Flows the Don went to United Artists, The Idiot to 20th Century Fox, Circus Stars to Paramount, Othello to Universal, and Don Quixote to Metro Goldwyn Mayer.36

These companies had the resources, experience, and clout to organize the widest possible exhibition of the exchange films; set beside these industrial giants, the efforts of Artkino, no matter how well intentioned or ambitious, appeared insignificant. The advertising materials for the exchange films have the same polished sophistication as those for American films of the era. The dimensions and graphics of newspaper advertisements, for example, made Artkino's mats look puny and crudely drawn by comparison. The studios also issued 'exhibitors' campaign manuals' to help individual theater owners promote the films. The manual that 20th Century Fox compiled for The Idiot displayed slides and 'telops' for advertising the film on local television stations (and available for purchase from a separate firm). It also featured a section whose headline banner urged exhibitors to 'Make Use of USA USSR Exchange Publicity.' Suggestions included special screenings for book clubs, literary societies, library and bookstore patrons, as well as teachers and students at both the high school and college level (the September opening of The Idiot, so the manual pointed out, made this strategy particularly well timed); lobby displays comparing stills from the movie with those from some of the classics directed by Sergei Eisenstein; and a writing contest (with newspaper coverage) based on a comparison of the Soviet film and 'U.S. made product.' Paramount's promotional booklet for Circus Stars, meanwhile, urged theater owners to 
'make your lobby look as circusy as you can possibly can' with the help of balloons, pennants, and 'a giant seeboard listing all the fabulous acts in the picture.'

These materials, moreover, consistently highlighted the official character of the event. Every newspaper ad, for instance, bore the following inscription, usually at the bottom: 'This picture is being distributed by [the releasing studio] at the request of the US State Department pursuant to the Cultural Exchange Agreement with the Soviet Union.' A similar statement appeared at the beginning of every Soviet exchange film. It informed audiences that they were taking part in a historic occasion but also left no doubt that the initiative in giving Soviet movies the deluxe treatment in America had come from their own government, not Hollywood.37

From the outset, the Soviets had sought the widest possible distribution of their films. In a show of good faith and given the Soviet hunger for American movies good business sense, they insured that the US exchange films would have playdates everywhere in the Soviet Union. The kick off movie Marty, for example, was booked into several Moscow cinemas simultaneously, including the 1500 seat Udarnik, where it reportedly played to packed houses. The other films in the package had staggered openings, so that the second film in the series, The Great Caruso with singer Mario Lanza, began playing throughout the country the following spring. Concern about the possible impact of US Soviet relations on the exchange developed when, in May 1960, the Soviets shot down the U 2 spy plane of American pilot Gary Powers, whereupon Premier Khrushchev angrily withdrew from a highly anticipated summit conference with President Eisenhower. The Soviets, however, adhered to the agreement, showcasing the US movies all over the country. 38

The situation regarding the Russian films in the USA was problematic. Even before all seven movies were in release, industry analysts began offering postmortems. For example, Variety correspondent Vincent Canby reported some interesting data regarding the box office performance of all of the films except Don Quixote, which had not yet opened. The most successful of the films was Circus Stars, the one that, on the surface, appeared least prestigious. It had had 4907 engagements and promised to show a profit. Swan Lake and The Cranes Are Flying followed at some distance; each had played in only slightly more than 100 theaters (compared with the 500 or so US cinemas that regularly programmed art films at that time) and grossed about $\$ 90,000$. Trailing still further behind were Othello and The Idiot, each of which had had only eight engagements for a box office take of $\$ 2200$. Their failure to attract an audience might have stemmed in part from the poorly synchronized (and widely criticized) dubbing of the dialogue, especially in the case of the Shakespearean drama. The US studios that had agreed to distribute the films were likely to incur a loss, but Canby shed no tears for them. For one thing, their financial burden would be lessened by an earlier agreement of the studios to pool the income from all of the films and then divide it equally. For another, the studios had only themselves to blame, taking on a task admittedly, under duress for which they had no particular enthusiasm or expertise. Films of the kind that the Soviet Union had sent to America were not their me tier. As a result, they treated them to quote another commentator on the subject 'like unwanted stepchildren' and, outside of a few major urban markets, denied them the special handling they required, often banishing them to the lower berth of a double bill. Meanwhile the independent releasing companies and art houses that could have provided this treatment were shut out of the process altogether.39

If US industry executives considered the film exchange a letdown, their Soviet 
counterparts dubbed it a swindle. Or at least that was the account offered by none other than Artkino president Nicholas Napoli. Even as the US Soviet film exchange was being negotiated, Napoli expressed concern that the Soviets were putting too much trust in the ability of major US film companies to distribute their films on a widespread basis in America. He also feared that, in its enthusiasm for making deals with major US film companies, Sovexportfilm was pushing Artkino to the side so that the smaller firm was now lacking for Soviet films to distribute. The results of the film exchange seemed to bear out some of Napoli's predictions. Conveying reactions gleaned from his contacts in the USSR, Napoli said that the Soviets had been miffed by the generally halfhearted marketing efforts of the Americans on behalf of the Russian films, especially when contrasted with the red carpet treatment they had accorded the US movies. At the same time, the larger number of US films purchased by the Soviets had meant sizable earnings for the Americans up front. Soviet disappointment in the film exchange may have helped revive their willingness to negotiate with Artkino. In 1961, Napoli was preparing to import one of his largest batches of new Soviet featuresinto America.40

Indeed Artkino's business remained healthy through the middle of the next decade. Between 1961 and 1964 the company programmed an average of nearly 14 films per year, two thirds of which were dramatic features. Many of them belonged to the familiar genres that remained staples of Soviet film making as well as the Artkino catalog cinematic adaptations of the literary classics, ballet and opera films, musical comedies, and children's movies. The repertoire of these years also included several notable 'thaw' films. Some continued to deal with World War II in increasingly realistic fashion. BothThe Day the War Ended (1959/1961) and Peace to Him Who Enters (1961/1963), for example, offered surprisingly downbeat views that sharply contrasted with the uplift and heroism of earlier war movies. In fact, the much lauded Peace to Him Who Enters, in which a trio of Russian soldiers helps to care for a pregnant German woman, was attacked by the Soviet army newspaper Red Star for its pacifism and refusal to assign blame for the war.41 Soviet science, officially as revered as the wartime experience, also came in for some revisionism. The Letter That Was Never Sent (1959/1962), for example, challenges the notion that scientific progress justifies the loss of human life (represented in this case by the four doomed members of a geological expedition to Siberia). Even more daringly, Nine Days of One Year (1962/1964), whose protagonist is dying of radiation poisoning, calls into question the value of atomic research, another Soviet article of faith. Artkino's selections of the early 1960s also included some 'thaw' comedies, which directed their barbs more pointed than ever at traditional Soviet institutions. Grown Up Children (1962/1963), for instance, took aim at extended households in which newlyweds rubbed shoulders with their parents. Welcome, Kostya! (1964/1965) wittily celebrated the pranks of youngsters who continually undermined the authority of their summer camp director.42 Several of Artkino's more interesting selections represented the early (sometimes the initial) works of promising new directors, including Kostya's Elem Klimov, Tengiz Abuladze (Stepchildren [1958/1962]), and Andrei Tarkovsky (Violin and Roller [1960/1962])).

Nevertheless Artkino's preeminence as a distributor of Soviet films, based on its long standing relationship with Sovexportfilm, was nearing an end. Competitors had begun to emerge around the time of the US USSR film exchange. In fact, even though the exchange itself posed no more than a short lived challenge to Artkino, it spurred independent releasing and distributing companies to enter the fray and take advantage of the artistically superior (and potentially lucrative) films that the 'thaw' had generated. A notable figure in this activity was J. Jay Frankel, the intrepid young president of M. J. P. 
Enterprises, a firm that sold American movies to Eastern Bloc countries. Frankel was temporarily stymied by the State Department's ban on independent deals with the Soviet Union during negotiations for the film exchange. Once the ban had been lifted, however, he acquired the rights to the Russian full length animated feature The Snow Queen (also known as The Snow Princess and based on a story by Hans Christian Andersen) and sold them to a business group headed by Stephen Vorhees for $\$ 25,000$. Vorhees turned a profit of $\$ 5,000$ when he sold the film to Universal Pictures, ironically one of the studios involved in the film exchange. With a new musical sound track and voices provided by American actors, The Snow Queen had its US premiere during the Easter season in 1960 and proved a much better draw than the poorly dubbed Othello, Universal's exchange film.43

Frankel scored a much bigger coup when he acquired the rights to Ballad of a Soldier (1959/1960), another 'thaw' inspired account of World War II that focuses on a young war hero trying to reach his home during a brief leave of absence. Ballad received reviews even more favorable than those for The Cranes Are Flying and won a couple of major awards at the San Francisco Film Festival. Frankel was unaware of it at the time, but he had not been alone in trying to snag Ballad for US moviegoers; several major American studios had submitted larger bids on the film. Asked to explain his success, he suggested that the Soviets, upset about the poor marketing of the exchange films in the USA, responded favorably when he promised to show Ballad to as many Americans as possible. (The Soviet willingness to deal with companies other than Artkino might also indicate some dissatisfaction with the familiar and relatively limited number of outlets that that firm had cultivated.) Frankel made an arrangement with Kingsley International to distribute the film in the USA. It marked the first time a Russian movie would be independently distributed under the US Soviet cultural exchange program. 44

Ballad of a Soldier had its US premiere late in 1960. The rest of the decade would see the periodic release of other films lacking the Artkino imprimatur. The total number was only a dozen or so, but in general they represent a more distinguished cross section of Soviet cinema than the Artkino repertoire of the same era, which, as always, varied considerably in quality. Independent distributors, seeking to serve a growing art house clientele, tended to be more selective in their bookings; by contrast, Artkino had always sought to convey a sense of Soviet film output across the board, including works that appealed to mass tastes. The opening of Ballad of a Soldier was followed a few months later by Fate of a Man (1959/1961) still another well reviewed Soviet war drama under the banner of United Artists. The company had acquired the film by means of a private deal outside of the cultural exchange agreement while executives were visiting Moscow for the premiere of Marty in November 1959.45 Subsequent non Artkino releases included A Summer to Remember (Seryozha) (1960/1961), the first of a spate of child's eye views of the world (Frankel/ Kingsley International); My Name Is Ivan (Ivan's Childhood) (1962/1963), Andrei Tarkovsky's searing portrait of a young boy destroyed by his experiences as a spy for the Red Army during World War II (Sig Shore); a film version of Nikolai Gogol's story The Overcoat (1964/1965) (Cinemasters International, Ltd.); Grigory Kozintsev's starkly elegant filmization of Hamlet (1964/1966) (United Artists); and the romantic comedy Meet Me in Moscow (1964/1966) (Frankel/Accord International Corporation). Moreover, just as Soviet films were coming to US shores already laden with awards from international festivals, they also began to appear more frequently at American film fests. Hamlet, for example, had its American premiere at the 1964 New York Film Festival (nearly two years prior to its regular run), and Sons and Mothers (1966/1967), a tribute to Lenin and a throwback to the pre 'thaw' era, got its 
start at the same event in 1967.46 The festival appearances not only lent prestige to the films but also helped them find distributors other than Artkino.

Another explanation for Artkino's diminishing presence in film distribution might be suggested by the agreement reached on bringing the mammoth Soviet production of War and Peace (1967) to American screens. Estimated to be the most expensive film ever made to that time and clocking in at nearly seven and a quarter hours, War and Peace was divided into two separate films and exhibited on a roadshow basis. In 1969, it also became the first Soviet film to win the Academy Award for Best Foreign Language Film. Distribution rights for the USA and Canada went to the Walter Reade Organization as the result of negotiations conducted by the Satra Corporation, a firm that specialized in US Soviet trade and cultural exchanges. The cost was $\$ 1,500,000$, paid in cash. When, a couple of years later, Commonwealth United secured the rights to the Soviet film version of Anna Karenina (1971), it had to pay a quarter of a million dollars more.47 Cinematic spectacles such as War and Peace and Anna Karenina might have been the exceptions to the rule, but they suggested that international film distribution was becoming a very big business indeed, perhaps a little too big for a modestly sized organization whose chief resource had been devotion to a cause.

Artkino's devoted managers acknowledged its decline in stature. A few months before her death in 1970, Rosa Madell, writing to the head of the American Department at Sovexportfilm in Moscow, lamented the fact that only 'lesser pictures' were now available to Artkino. At the same time, she held out the hope of a turnaround in the company's fortunes.

But, nevertheless, we are convinced that Artkino Pictures can still play an Important and necessary role in keeping Soviet films before the American public. I am sure that you will agree with us that the basic audience for Russian films which we have nurtured and catered to for so many years must not be allowed to disintegrate waiting for the occasional big picture to be released in this country. It can be kept alive only via a steady flow of Russian language film product, and it is in this area that we can serve.48

Likewise, her husband Sam complained that booking New York theaters had become a particular challenge 'because the major companies practically have a monopoly on the playing time.' A few years later, fishing about for an idea to boost business, he suggested to Sovexportfilm the creation of a lottery that would enroll anyone who bought a ticket to see a Soviet film in the USA. The grand prize would be an all expenses paid trip to the Soviet Union, including a tour of the Mosfilm studio. Sam's proposal had no takers. 49

The Madells continued to be the guests of Sovexportfilm at the Moscow Film Festival every summer and saw the latest Soviet movies. New films appearing under the Artkino banner, however, became fewer and more sporadic. After 1964 (with its 14 releases), the number dropped to five each in 1965 and 1966, one in 1967, two in 1969 , one in 1970, five in 1972, and finally three in 1975.50 At the same time, the staff, which probably numbered no more than half a dozen people even during World War II, dwindled to one or two.

Trying to remain engaged in the business even as new films became fewer and more difficult to procure, Artkino increasingly turned its attention to older releases. For example, it acquired the rights to some of the Russian films that had been part of the 
original US Soviet exchange as well as a few films that had initially appeared under the auspices of other distributors. With these works the goal became bookings at revival houses, retrospectives and film societies, not first run theaters. In 1969, Artkino packaged an all Eisenstein program consisting of a new sound version of the director's Ten Days That Shook the World (1928) and the partially restored Bezhin Meadow (1937). The next year it programmed a Soviet film festival at a Manhattan theater to coincide with the centenary of Lenin's birth. Artkino also brokered the sale of Soviet films to television networks and tried monitoring the use of film clips and stills from Soviet films in the US media, although its attempts at seeking compensation for such material sometimes elicited curt refusal.51

In later years, Artkino made available parts of its film library to other companies as subdistributors. Occasionally, though, these arrangements ended in legal feuds that continued long beyond Artkino's active involvement in film distribution. This situation had its origins in a 1954 agreement with Brandon Films, Inc. (later Audio Brandon, then Macmillan Films), allowing that firm to license $16 \mathrm{~mm}$ prints of selected Soviet films for non theatrical use. Artkino made a similar agreement with Janus Films, Inc., in 1972. In August 1973, Sam Madell visited Moscow to hammer out a new general agreement between Artkino and Sovexportfilm, the first in a decade. In general, it called for the gradual return to the Soviet agency of the rights to more than 200 films that Artkino had acquired since 1940. In other words, Artkino not only had ceased to be a distributor of new Soviet films but was now also losing the library of older Soviet films it had accumulated over the years. Under the circumstances, Brandon would now be obligated to relinquish its rights to the films to which Artkino had granted it access and to return to Artkino all of the negatives and prints it had acquired since 1954. Brandon, however, refused, and Sam Madell eventually resorted to legal action. In 1985, he was awarded a settlement of $\$ 120,000$. In 1990, now completely retired from the business, Madell moved to Berkeley, California, where he passed away in 2001.52

Perhaps the financial settlement in1985 helped to compensate for a different kind of loss that had occurred several years earlier. In 1979, Sovexportfilm, which by now had severed all ties with Artkino, entered into an agreement with Corinth Films, Inc., making them the exclusive distributor of approximately 100 Soviet films in the USA. These, however, were all older releases. To handle their latest works, the Soviet film establishment continued relying on a variety of newer and more aggressive firms, such as International Film Exchange (IFEX).53 The arrangement with Corinth simply emphasized that Artkino had nothing further to do with the distribution of Soviet films, new or old. It also suggested that the days when a single firm had a monopoly on Soviet film distribution in the USA had, ironically, yielded to the competition of the market.

For 35 years, during wars both hot and cold as well as periods of thawing out, Artkino kept interested moviegoers apprised of the state of Soviet cinema with a steady stream of dramatic features and documentaries. Compared with the 1940s and early 1950 s, the new artistic creativity born of Khrushchev's reforms gradually altered the content of what US audiences saw from the USSR, but the number of its cinematic exports remained approximately the same as before. The official US USSR film exchange of the late 1950s had the effect of temporarily reducing the flow of Soviet films into America. Yet that brief episode proved to be a turning point. It demonstrated that the distribution of foreign language (and specifically Soviet) films was best left to independent, specialized firms adept at their handling rather than the traditional Hollywood giants accustomed to mass marketing a more standardized product. At the 
same time, the official film exchange, which had been so disappointing on the surface, created openings and highlighted opportunities for newer, more innovative companies. For them the thaw was particularly significant, because it drew their attention to the renewed artistry of the Soviet cinema, which had never been a particular or certainly an exclusive concern of Artkino. Suddenly Soviet films became objects of desire, and Artkino discovered that it had competitors. Furthermore, the newer distributors not only promised to circulate Soviet films more widely in the USA (and elsewhere) than before; they could also satisfy the ever present but always increasing desire of the Soviet government and film establishment for larger infusions of cash. In other words, they could offer more sophisticated marketing expertise and greater financial resources than Artkino everknew.

In some respects, that company, with its temporary monopoly over Soviet film distribution in America, was a holdover from an earlier era, reflecting the top down control that characterized Stalin's Russia. For several decades Artkino had performed yeoman's service, laying a solid basis for the continuing development of the US Soviet film trade and satisfying a devoted niche audience. Its members were drawn to the Stanley or the Cameo out of ideological sympathy for the Soviet Union, love of Russian culture, or some combination of the two. They were not necessarily the same people who flocked to foreign language films in increasing numbers after World War II out of an interest in the cinema as art. So, like other vestiges of the pre thaw era in the Soviet Union, Artkino had to yield to more modern and flexible approaches and different tastes that only a newer generation of film distributors could provide. Artkino, which had long tried strengthening US Soviet ties through the movies, not only failed to benefit from the thaw but also became one of its casualties.

\section{Notes}

1 Press release of the Film Guild, 1959, Art. 739, Artkino Corporation Collection, Museum of Modern Art, New York, New York (hereafter Artkino/MOMA).

2 The Artkino collection at the Museum of Modern Art consists of 23 boxes of documents that deal mostly with specific Artkino releases, including business files, scripts, publicity materials and film stills. They were donated to MOMA in 1975 by Mr. Sam Madell, Artkino's last president. I am indebted to Mr. Charles Silver, director of the museum's Department of Film, for his generous assistance in consulting this collection during my two visits to MOMA. References to it in the footnotes are limited to representative examples. While the Artkino collection at the Pacific Film Archive is much smaller and appears to duplicate some of the publicity materials from MOMA, it also includes a couple of boxes of additional documents donated to PFA in 2002 by Sam and Rosa Madell's son Tom that are not part of MOMA's holdings. My thanks go to Ms. Nancy Goldman of the Pacific Film Archive for allowing me access to these recent acquisitions, which are not catalogued as of this writing. For their helpful and informative responses to my questions, I am also grateful to Tom Madell, his brother Rob Madell, and Ms. Lenore Napoli Lev, the daughter of Nicholas Napoli, Artkino's first president. Additional research was carried out at the Margaret Herrick Library of the Academy of Motion Picture Arts and Sciences in Beverly Hills, California. Finally, I wish to express my gratitude to Drs. Brenda Wirkus and Pamela Mason of John Carroll University for their encouragement and insightful criticisms of the text.

3 Soveksportfilm, Kino entsiklopedicheskii slovar', ed. S. I. lutkevich (Moscow, 1986), 394; Serge A. Kouzmitchev, Sovexportfilm transition from propaganda to profits, 
Variety, July 5, 1989, p. 36.

4 Soviet Russia, 193637 International Motion Picture Almanac (New York, 1936), 1098. Soviet films are identified by the English language titles under which they were released in America. They are accompanied by the year of their release in the USSR followed by the year of their US release as indicated by their playdates in New York City, e.g. 1954/1955. A film whose US release occurred in the same year as its Soviet release is accompanied by that year alone.

$5 \quad$ Soviet Film Runs in U.S. Suspended, New York Times, February 3, 1940, p. 9; Thomas M. Pryor, The Soviet Fadeout, New York Times, February 11, 1940, IX, p. 4; Liquidated, Time, February19, 1940, p. 47.

6 Agreement between Artkino and Soyuzintorgkino, March 1, 1940, Artkino collection, Pacific Film Archive (hereafter Artkino/PFA); To Resume Soviet Films, New York Times, March 10, 1940, p. 40; Thomas M. Pryor, By Way of Report, New York Times, April 6, 1941, p. 22.

719401941 Motion Picture Almanac (New York, Quigley Publishing, 1940), 441. In the 1920s, Napoli reportedly edited II Lavoratore ('The Worker'), a Communist newspaper published in New York. His ideological sympathies appear to have caused him trouble. Napoli's daughter Lenore recalled visits to the family residence after the war by the FBI, although nothing ever came of them. In 1995, decades after his death, the US government officially removed the veil of secrecy from the Venona Project, which, between 1946 and 1981, had translated more than 2900 messages sent between the New York office of the KGB and KGB headquarters in Moscow during World War II. Venona purported to show that the Soviet Union had recruited spies throughout American society, including its military and diplomatic agencies. One of the translated messages names Napoli as an informant. Venona, however, has also come under criticism for demonizing individuals whose contacts with Soviet agents were entirely innocent. John Earl Haynes and Harvey Klehr, Venona: decoding Soviet espionage in America (New Haven, 1999), 8 22, 359, 458n215; Victor Navasky, Cold War Ghosts, Nation, July 16, 2001, 5. Rosa Madell's reminiscence about seeing The Battleship Potemkin is found in an undated manuscript in the PFA's Artkino collection.

$8 \quad$ The 1941 Film Daily Year Book of Motion Pictures (New York, 1941), 225; Peter Kenez, Cinema and Soviet Society, 19171953 (New York, 1992), 186188.

Lenore Napoli Lev, the daughter of Nicholas Napoli, said that World War II effected a complete turnaround in the business fortunes of Artkino; in her words, it was a veritable 'gold rush.' Telephone conversation with Lenore Napoli Lev, July 8, 2008.

9 David Platt, Soviet Films Enter New Era, Daily Worker [New York], March 25, 1946, p. 11; Vodkaites Veering to Revusicals, Says USSR Rep; New 3d Dimension, Variety, March 13, 1946, p. 15; Nicholas Napoli, Film Notes of a Trip to the USSR, manuscript of article later published in Russian in Russkii golos, April 21, 1946, p. 5, Artkino collection, Pacific Film Archive (hereafter Artkino/PFA).

10 Kenez, 235239.

11 The postwar rise of the foreign language film and 'art house' cinema in America is the subject of Barbara Wilinsky's Sure Seaters: the emergence of art house cinema (Minneapolis, 2001).

12 William Taubman, Khrushchev: the man and his era (New York, 2003), 306 10, 382 88; Josephine Woll, Real Images: Soviet cinema and the thaw (London, 2000), x. 13 Bosley Crowther, rev. of The Ballet of Romeo and Juliet, New York Times, April 3, 1956, p. 31. The film was distributed by Tohan Pictures.

14 A. Weiler, rev. of A Big Family, New York Times, June 6, 1955, p. 24; Woll, 1619. 15 'M. E.' [Milton Esterow], rev. of Conflict, New York Times, December 26, 1955, p. 23; Esterow, rev. of The Case of Sergei Rumyantsev, New York Times, November 26, 
1956, p. 22; Howard Thompson, rev. of The Forty First, New York Times, June 15, 1957, p. 10; Alan Stanbrook, The Legacy of the Thaw, Films and Filming 6 (November 1959),

8; A. H. Weiler, rev. of Carnival in Moscow, New York Times, November 4, 1957, p. 40; Thompson, rev. of The House I Live In, New York Times, April 20, 1959, p. 34.

16 As an example, the print ad for Devotion describes it as 'Something new in Soviet films.' New York Times, July 30, 1955, p. 14.

17 See e.g. press release, January 29, 1946, Art. 739, Artkino/MOMA; Artkino Sets 10USSRFilmsforNext Season,Variety,August16,1967,p.15.

18 Subtitling occurred almost exclusively on dramatic features. By contrast, documentaries usually had English narration, which was supplied in the Soviet Union. Napoli had tried generating interest in dubbing rather than subtitling dramatic features during World War II but to little effect. See, for example, the transcript of a talk that he delivered at a film exhibitors' meeting in Toronto in August 1943. Speech by N. Napoli at Convention of Empire Universal Film, Ltd. at Hotel Royal York, Toronto August 14, 1943 , Artkino/PFA.

19 Art. 229, Artkino/MOMA. The cut lines are as follows: 1) 'Energy means light, heat, plenty. Means Communism.' 2) 'People who build Communism ought to be kind hearted.'

20 Howard Thompson, rev. of Cavalcade of Russian Ballet and Dance, New York

Times, May 31, 1965, p. 8.

21 Wilinsky, 2527.

22 Art. 103, 217, 328 (applications for motion picture exhibition licenses); Art. 80

(Festival in Moscow), Artkino/MOMA. The quotation comes from Howard

Thompson's review of Festival in Moscow, New York Times, February 17, 1958, p. 19.

23 'E. J. B.' [Edmond J. Bartnett], rev. of Village Teacher, New York Times, July 5, 1948 , p. 8.

24 Art. 739, Artkino/MOMA; Bosley Crowther, rev. of Boris Godunov, New York Times, January 23, 1956, p. 21.

25 Art. 730, 731, 732 (booking records), Artkino/MOMA.

26 Playdate Status of Russ Pix Here, Variety, September 10, 1958, p. 5.

27 About newspaper and radio advertising, see e.g. materials about Son of the Regiment, Art. 302, Artkino/MOMA; invitation to a preview of Grown Up Children, Art. 112 and 113. For a sample list of advertising materials, see Art. 233 and 234 about Peace to Him Who Enters.

28 Examples of advertising mats can be found among materials relating to many films, including Queen of Spades, Art. 252 and 253, Artkino/MOMA.

29 Esterow, revs. of American Farmers Visit Russia, New York Times, November 3, 1955, p. 37, and Porgy and Bess documentary, New York Times, June 11, 1956, p. 26. American Farmers opened at the Stanley in November 1955. The documentary about the Porgy and Bess troupe played the Cameo in June 1956.

30 MPEA Still Getting a Typical Soviet Stall on Pix, Variety, July 19, 1950, p. 37.

31 United States and U.S.S.R. Sign Agreement on East West Exchanges,

Department of

StateBulletin 38 (February 17, 1958), 24348.

32 Variety's coverage of the US Soviet film negotiations is extensive; three especially informative articles are the following: 'Favors' to RussiansMight Inspire Other Nations to Pressure Yanks, March 5, 1958, p. 16; Fred Hift, Soviets' Theme Is 'Mutuality', April 23, 1958, pp. 3, 16; Yanks Find 'Em Hard Bargainers, May 7, 1958, p. 5.

33 United States and U.S.S.R. Agree on Films To Be Exchanged, Department of State Bulletin 39 (November 3, 1958), 696698.

34 Soviet Yank Synchronized Premieres, Variety, March 25, 1959, p. 14. The USSR 
had begun attending Cannes on a regular basis in 1954. While earlier Soviet films had won awards at the festival, Cranes was the first (and, as it would turn out, the only) Soviet entry to snag the Palme d'Or. Kieron Corless and Chris Darke, Cannes: inside the world's premier film festival (London, 2007), 2931.

35 Washington Moscow Premieres, Variety, November 18, 1959, p. 22; Max Frankel, U.S. Movie Series Opens in Moscow, New York Times, November 11, 1959, p. 23.

36 Seven U.S. Distribs Draw Straws; But Share Costs and Receipts In Soviet Films Under U.S. Deal, Variety, July 1, 1959, pp. 3, 18.

37 Clipping files for the exchange films are available at the Center for Motion Picture Study of the Margaret Herrick Library, Academy of Motion Picture Arts and Sciences, in Beverly Hills, California.

38 George Katznelson, Moscow Day Dates America's 'Marty', Variety, November 25, 1959, p. 2; Lanza's 'Caruso' Now Plays USSR; State Sees No Break in Exchange, Variety, May 25, 1960, p. 1 . The films evidently continued to play throughout the country for some time to come. For example, the author saw The Seventh Voyage of Sinbadata Leningrad area theater in August1978.

39 Vincent Canby, So What's New With USSR?, Variety, November 16, 1960, pp. 5, 24; Art Manager Chides Majors, Variety, December 7, 1960, pp. 7, 11.

40 Film exchange negotiations, unpublished manuscript, August 29, 1958, Artkino/ PFA; Russian Evaluation of Swap: Yanks Got More Than They Gave, Variety, February22, 1961, p. 4.

41 Russo Army Paper Raps The Prizewinning Soviet Pic for Its Pacifism, Variety, October 18, 1961, p. 17; Woll, 12124.

42 All of the following reviews come from the New York Times: Howard Thompson, rev. of The Letter That Was Never Sent, November 19, 1962, p. 39; Bosley Crowther, rev. of Nine Days of One Year, December 29, 1964, p. 19; Thompson, rev. of Grown Up Children, April 15, 1963, p. 36; Thompson, rev. of Welcome, Kostya!, November 22, 1965, p. 48.

43 J. Jay Frankel, Film Trading With Reds No Picnic But Could Hit \$1,500,000 in '59, Variety, January 21, 1959, p. 22; Clear Path for Private Enterprise With Soviet Film Trust But U.S. Showmen Oughta Check Shelton, Variety, April 15, 1959, p. 5; Univ. Pays $30 \mathrm{G}$ For U.S. Rights to Soviet Cartoon, Hollywood Reporter, June 5, 1959, p. 7; Hold 'Snow Queen' From Russia for Easter Period, Variety, October 7, 1959, p. 3.

44 How Hardy Young Importer Got Rights to Prize Red Film, World Telegram and Sun Feature Magazine Section, March 27, 1961, p. 4; Theory: Arty Showmen Better Bets to Handle USSR Product in U.S., Variety, November 2, 1960, p. 4.

45 Hollywood Reporter, December 1, 1959, p. 5.

46 All of the following reviews come from the New York Times: Bosley Crowther, rev. of Fate of a Man, July 11, 1961, p. 28; Crowther, rev. of A Summer to Remember, November 7, 1961, p. 38; Crowther, rev. of My Name Is Ivan, June 28, 1963, p. 25; Crowther, rev. of The Overcoat, March 2, 1965, p. 31; Crowther, rev. of Hamlet, March 16, 1966, p. 48; Vincent Canby, rev. of Meet Me in Moscow, May 3, 1966, p. 51; Howard Thompson, rev. of Sons and Mothers, October 2, 1967, p. 58.

47 Lee Beaupre, Showmanship Links U.S. USSR, Variety, April 7, 1968, p. 3; USSR's 'Karenina' Fetched \$1,742,500; Satra Took Stock, Variety, July 16, 1969, p. 17.

48 Letter, Rosa Madell to Stanislas N. Belousov, September 17, 1969, Artkino/PFA.

49 Letter, Sam Madell to S. Belousov, February 17, 1969; letter, Sam Madell to V. Yaroslavtsev, March 7, 1973, Artkino/PFA.

50 Moscow Fest Winners Go To U.S. Domestic Market Via Artkino's Rosa Madell, Variety, August 4, 1965, p. 9; Artkino Sets 10 USSR Films for Next Season, Variety, August 16, 1967, p. 15. 
51 Letter, Sam Madell to Joseph De Louise, March 28, 1969; letter, Sam Madell to S. Belousov, November 17, 1970; letter, Sam Madell to NBC Television Network, May 4, 1972; letter, CBS Television Network to Artkino Pictures, Inc., March 14, 1974; letter, Sam Madell to NBC News, April 27, 1970; letter, John E. Ghilain (NBC Television Network) to Sam Madell, May 11, 1970; letter, Karen L. Henard (Bobbs Merrill Company, Inc.) to Sam Madell, February 7, 1975. All of these documents come from the Artkino/PFA collection.

52 Letter, N. Napoli to T. J. Brandon, March 1, 1954; letter, A. William J. Becker III (Janus Films) to Sam Madell, August 1, 1981; Agreement between V/O Sovexportfilm and Artkino Pictures, Inc., August 14, 1973 [English and Russian language versions]; letter, Samuel H. Golden to Samuel Madell, August 5, 1985; letter, Samuel H. Golden to Samuel Madell, September 24, 1985 (Artkino/PFA). E mail (April 18, 2008) from, and telephone conversation (April 22, 2008) with, Mr. Thomas Madell.

53 Agreement between Sovexportfilm and Corinth Films, Inc., June 7, 1979. Terry Ilott, IFEX stays ahead in taking art titles to US audiences, Screen International, October 27, 1984, n.p.

James H. Krukones joined the Department of History at John Carroll University in 1988 and has taught a variety of courses on Russia and Eastern Europe, Modern Europe, Western and World Civilization, historical methodology, and history on film. He also has served as an associate academic vice president since 2001. His Ph.D. in Russian history is from the University of Wisconsin-Madison (1983). 